\title{
Türkiye Hayat Sigortası Piyasasında Yoğunlaşma İle Etkinlik Arasındaki İlişki
}

\author{
Relationship Between Concentration And Effectiveness In The Turkish Life Insurance \\ Market
}

Arif $\dot{I} \breve{G} D E L I^{*}$

İbrahim BAKIRTAŞ**

\begin{abstract}
$\ddot{O} Z$
Bu araştırmanın amacl, 2009-2018 döneminde ayllk verilerden yararlanarak Türkiye hayat sigortası piyasasinda yoğunlaşmanın piyasa büyümesi üzerindeki etkisini incelemektir. Bu araştırmada piyasa yoğunlaşmasinin ölçümünde $C R_{4}$, HHI ve Entropi indeksleri kullanılmıştır. Johansen eşbütünleşme testi bulgularında Türkiye hayat sigortası piyasasında yoğunlaşma ile piyasa büyümesi arasında uzun dönemde anlamlı bir ilişsi tespit edilmişstir. Ayrıca DOLS, FMOLS ve CCR tahmin bulgularına göre $H H I$ ve $C R_{4}$ değerleri ile piyasa büyümesi arasında negatif yönlü ilişki bulunurken, Entropi değerleri ile piyasa büyümesi arasinda pozitif yönlü ilişsi bulunmaktadır. Analizden elde edilen bu bulgular SCP yaklaşımında öne sürülen yoğunlaşma ile piyasa büyümesi arasındaki negatif yönlü ilişskiyi doğrulamaktadır. Bu bulgulara göre hayat sigortası piyasasında etkinliğin geliştirilmesi için rekabeti destekleyici politikaların üretilmesi gerekmektedir.
\end{abstract}

\section{ANAHTAR KELIMELER}

Yoğunlaşma, Hayat Sigorta Piyasast, Piyasa Büyümesi, DOLS, FMOLS

\begin{abstract}
The aim of this research is to examine the impact of concentration on the market growth in the Turkey life insurance market, benefiting from 2009-2018 monthly data. CR, HHI and Entropi indices were used in the measurement of market concentration in this research. A significant relationship was found between concentration and market growth in the long term in the analysis of Johansen co-integration test findings. In addition, according to DOLS, FMOLS and CCR estimation findings, there is a negative correlation between $\mathrm{HHI}$ and $C R_{4}$ values with market growth, while there is a positive relationship between entropy values and market growth. These findings obtained from the analysis confirm the hypothesis of the existence of a negative correlation between market growth and the concentration proposed in the Traditional Structure-Behavior-Performance approach. According to these findings, in order to effectiveness in the life insurance market, policies supporting competition should be produced.
\end{abstract}

\section{KEYWORDS}

Concentration, Life Insurance Market, Market Growth, DOLS, FMOLS

\begin{tabular}{|c|c|c|}
\hline \multicolumn{2}{|r|}{$\begin{array}{c}\text { Makale Geliş Tarihi / Submission Date } \\
\text { 29.07.2019 }\end{array}$} & $\begin{array}{c}\text { Makale Kabul Tarihi / Date of Acceptance } \\
\text { 07.11.2019 }\end{array}$ \\
\hline Atıf & $\begin{array}{l}\text { İğdeli, A. ve Bakırtaş, İ. (2019). Tür } \\
\text { Selcuk Üniversitesi Sosval Bilimler M }\end{array}$ & $\begin{array}{l}\text { yasasında Yoğunlaşma İle Etkinlik Arasındaki İlişki. } \\
s i, 22 \text { (2), 825-839. }\end{array}$ \\
\hline
\end{tabular}

\footnotetext{
* Dr. Öğr. Üyesi, Aksaray Üniversitesi, İktisadi ve İdari Bilimler Fakültesi, İktisat Bölümü, arifigdeli@ hotmail.com, ORCID: 0000-0002-5926-425X

*** Prof. Dr., Aksaray Üniversitesi, İktisadi ve İdari Bilimler Fakültesi, İktisat Bölümü, ibakirtas@aksaray.edu.tr , ORCID:0000-0003-0945-2823
} 


\section{GİRIŞ}

İnsanoğlu, tarihin başlangıcından bu yana risk ve tehlikelere karşı kendini korumaya çalışmıştır. İnsanoğlunun bu çabası sigortacılık sektörünün dogmasına yol açmıştır (Akın ve Nalan, 2013: 90). Sigorta, ticari bir organizasyon aracıllı̆ıyla aynı risk ve tehlike altında bulunan kişilerin bir araya gelerek, gelecek dönemde meydana gelebilecek risk ve tehlikelerden doğacak olan zararların önceden yapılan ödemeler karşılığında güvence altına alınmasıdır (Güvel ve Güvel, 2012: 24). Kısaca; sigorta, risk ve tehlikelere karş1 satın alınan bir koruma aracıdır. Sigorta, hayat dışı sigorta ve hayat sigortası olmak üzere ikiye ayrılır. Hayat dışı sigorta, mülk ve zayiat gibi risk transferi ile ilgili alanları kapsar. Hayat sigortası ise ölüm veya sakatlık gibi kontrol dışı nedenlerle önceden belirlenmiş nakit akışının zamanlamasında ve büyüklügünde meydana gelecek sapmaları kapsar (Bikker ve Leuvensteijn, 2008: 2065). Hayat sigortası, sözleşmesinde poliçe sahibi tarafından belirlenen kişilere veya yasal mirasçılarına, sigortalının ölümü üzerine önceden belirlenmiş miktarda para ödemesi beklenen bir sözleşme olarak kabul edilir (Alhassan, vd., 2015: 651). Ertelenmiş tüketim olarak da tanımlanan hayat sigortası, insanlara ölüm veya hastalık gibi beklenmedik durumlarda finansal kaynaklar sağlar. İnsanların zamanlar arasında tüketimi düzleştirme isteği, miras ve vergi avantajları gibi motivasyonlar hayat sigortası sektörünün her geçen gün daha çok gelişmesine neden olmaktadır. Bu temel motivasyonlar hanehalkı üyelerinin gelir akımı konusunda kendilerini güvence altına alma gayretlerinden doğmuşlardır. Bu nedenle verimli işleyen bir hayat sigortası piyasası, toplumun zenginliğin korunmasına da katkı sağlayacaktır (Brekesova, vd., 2016: 29). Hayat sigortası satın alacak alıcı türüne ve ikame edilemezlik derecelerine bağlı olarak üçlü sınıflandırmaya tabi tutulabilir: (1) Normal hayat sigortası, (2) Grup hayat sigortas1 ve (3) Endüstriyel hayat sigortası. Normal hayat sigortası piyasasında alıcının ürün hakkında bilgisi ve pazarlık gücü düşüktür. Grup hayat sigortası ve endüstriyel hayat sigortası piyasasında ise alıcıların ürün hakkında bilgi düzeyi ve pazarlık gücü yüksektir (Cummins, vd., 1972: 178). Hangi tür olursa olsun sigorta piyasasının etkinliğini belirleyen iki temel unsur vardır. Bunlardan ilki asimetrik bilgi düzeyidir. Asimetrik bilgi arttıkça piyasanın etkinliği azalmaktadır. İkincisi ise ekonomik kaynak ve faaliyetler toplamının büyük bir kısmının, piyasadaki az sayıda birim tarafından kontrol edilmesi veya sahiplenilmesi şeklinde tanımlanan piyasanın yoğunlaşma düzeyidir (Yıldırım vd., 2016:21). Piyasa yoğunlaşma düzeyinin piyasanın etkinliği üzerindeki etkisi mevcut literatürde yer alan üç temel hipotezin hareket noktası olmuştur. Bunlar Geleneksel Yapı- Davranış- Performans (SCP) hipotezi, Etkin Yapı (ES) hipotezi ve Göreceli Pazar Gücü (RMP) hipotezidir.

SCP hipotezine göre piyasa yoğunlaşması ile piyasa etkinliği arasında doğrudan bir ilişki vardır. Piyasa etkinliğini; Çelik ve Kaplan (2007), Njegomir ve Stojic(2011), Pervan ve Kremaric (2012), Akel vd. (2016) gibi araştırmacılar karlılık; Fenn vd. (2008) gibi araştırmacılar verimlilik; Eissen (1991), Kozak (2011), Alhassan (2015), Cummins vd. (2017), Dimic vd. (2018) gibi araştırmacılar ise piyasa büyümesi gibi faktörlerle ölçmektedirler. SCP hipotezi, piyasa yoğunlaşması ile karlılık arasında pozitif yönlü bir ilişkinin varlığını, piyasa yoğunlaşması ile piyasa büyümesi arasında ise negatif yönlü bir ilişkinin varlığını savunmaktadır. SCP hipotezine göre uygun piyasa yoğunluğu seviyesi, rekabet için doğru koşulları sağladığı ve piyasa büyümesini hızlandırdığı için finansal kurumların işleyişini önemli ölçüde pozitif yönlü etkilemektedir. Sonuç olarak; şirketler daha rekabetçi hale gelecek ve müşteriler de sigorta kapsamı dâhilinde daha kaliteli ürün ve hizmetler elde edeceklerdir (Kozak, 2011: 41). Bu hipotezin teorik görüşleri, daha sonra ES hipotezi ile sorgulanmıştır. ES hipotezi, piyasa yoğunlaşması sonucunda pazar payı artan firmaların düşük fiyatlandırma ile daha yüksek satışlar üreteceğini savunmaktadır. Bu hipoteze göre piyasa yoğunlaşması ile piyasa büyümesi arasında pozitif yönlü bir ilişki vardır (Alhassan, vd., 2015: 649). ES hipotezi de daha sonra RMP paradigması olan alternatif bir görüşle sorgulanmış ve geliştirilmiştir. Bu hipoteze göre tüketiciler, büyük firmaların ürünlerini küçük firmaların ürünlerinden ayırmaktadırlar. Piyasada ürün farklılaşması gerçek olmak zorunda değildir, sadece ürün farklılaşmasının algılanması gerekir. Tüketiciler kalitenin göstergesi olarak pazar liderinin konumuna güvenebilir ve arama maliyetlerinden tasarruf edebilirler. RMP hipotezine göre piyasa yoğunlaşması ile piyasa büyümesi arasındaki ilişkinin yönü piyasadaki lider firmanın piyasa payına bağlıdır (Choi ve Weiss, 2005: 636). Gelecek vaat eden riskler ve tehlikelere karşı güvence olarak görülen hayat sigorta piyasasının Türkiye'deki gelişiminde bu hipotezlerden hangisinin geçerli olduğu araştırmanın temel motivasyon unsurudur. Bu temel motivasyona bağlı olarak araştırmanın üç amacı vardır. Bunlardan ilki Türkiye'de hayat sigortası piyasasının yoğunlaşma düzeyini belirlemektir. İkincisi Türkiye'de hayat sigortası piyasasında son on yılda görülen büyümenin piyasa yoğunlaşmasından kaynaklanıp kaynaklanmadığını tespit etmektir. Üçüncüsü ise Türkiye'de hayat sigortası piyasasında yoğunlaşma ile piyasa büyümesi arasındaki ilişkiyi temel hipotezler bağlamında tartışmaktır. Araştırmanın birinci amacı için piyasa yoğunlaşmasını hesaplamada yoğun olarak kullanılan üç indeksten yararlanılmaktadır. İkinci amacı için elde edilen piyasa 
yoğunlaşma düzeyleri ile piyasa düzeyleri arasındaki uzun dönemli ilişki Johansen eşbütünleşme yöntemi ile tespit edilmiş̧ir. Tespit edilen uzun dönemli ilişkinin tahmininde de Dinamik En Küçük Kareler (DOLS), Düzeltilmiş En Küçük Kareler (FMOLS) ve Kanonik Eşbütünleşme Regresyonu (CCR) yöntemlerine başvurulmuştur. Son amacı için ise bulgular bağlamında mevcut literatürdeki SCP, ES ve RMP hipotezlerinden hangisinin Türkiye hayat sigortası piyasası için geçerli olduğu tartışılmaktadır.

Motivasyonun ve buna bağlı olarak amaçların yer aldığ 1 giriş, genel değerlendirme ve tartışmaların yer aldığı sonuç bölümü hariç, araştırma dört bölümden oluşmaktadır. Giriş bölümünü takiben birinci bölümde Türkiye'de hayat sigortası piyasasının genel görünümüne ve piyasanın yoğunlaşma düzeyinin ölçülmesine yer verilmektedir. İkinci bölümde araştırmamıza rehberlik edecek alan yazını tanıtılmış ve ayrıca araştırmamızın özgün değeri belirtilmektedir. Üçüncü bölümde analizde kullanılacak olan veriler ve tahmin yöntemleri tanıtılmaktadır. Takip eden bölümde ise araştırmanın analizlerine ve bulgularına yer verilmektedir. Son bölümde ise bulgulara bağlı olarak sonuç ve değerlendirmenin yanında araştırma kısıtlarına da yer verilmektedir. Ayrıca bu bölümde hem politika yapıcılara hem de gelecekte bu konuyu çalışacak olan araştırmacılarına öneriler sunulmaktadır.

\section{TÜRKIYE'DE HAYAT SIGORTASI PIYASASININ GENEL GÖRÜNÜMÜ VE PIYYASANIN YOĞUNLAŞMA DÜZEYİ}

Türkiye, küresel düzeyde faaliyet gösteren hayat sigortası şirketleri için önemli piyasalardan biridir. Çünkü yüksek nüfus artışı, her geçen gün artan ortalama yaşam beklenti süresi ve hanehalkı gelir düzeyinin ortalama olarak yükselen bir seyir izlemesi gibi özelliklerinden dolayı Türkiye, gelecekte de hayat sigorta sektörünün aynı ivmeyle büyüme göstermesi beklenen bir ekonomidir. Türkiye'de 2000 yılından sonra hayat sigortası piyasasında faaliyete bulunan firma sayısı, hayat sigortası primlerinin toplam sigorta primleri içindeki payı, hayat sigortası primleri ve hayat sigortası yaptıran insanların sayısı gibi hayat sigortası şirketlerinin yakından takip ettiği göstergeler üzerinden bu piyasanın görünümü hakkında genel bir değerlendirme yapılacaktır. $\mathrm{Bu}$ seçilmiş göstergelerin yer aldıgı grafikler Şekil 1'deki dört panel yardımıyla resmedilmektedir.

Şekil 1 Panel A'ya göre 2001-2015 döneminde firma sayıları doğrusal bir trend eğiliminde değildirler. Aksine bu dönemde firma sayıları yüksek düzeyde olmasa da dalgalanma göstermektedir. Ancak ilginç olan 2016 yılından sonra piyasadaki firma sayısında keskin bir düşüş gözlenmektedir. 2016 yılında firma sayısı 23 'e düşmüş ve ilerleyen dönemde firma sayısı 23 'te kalmıştır.

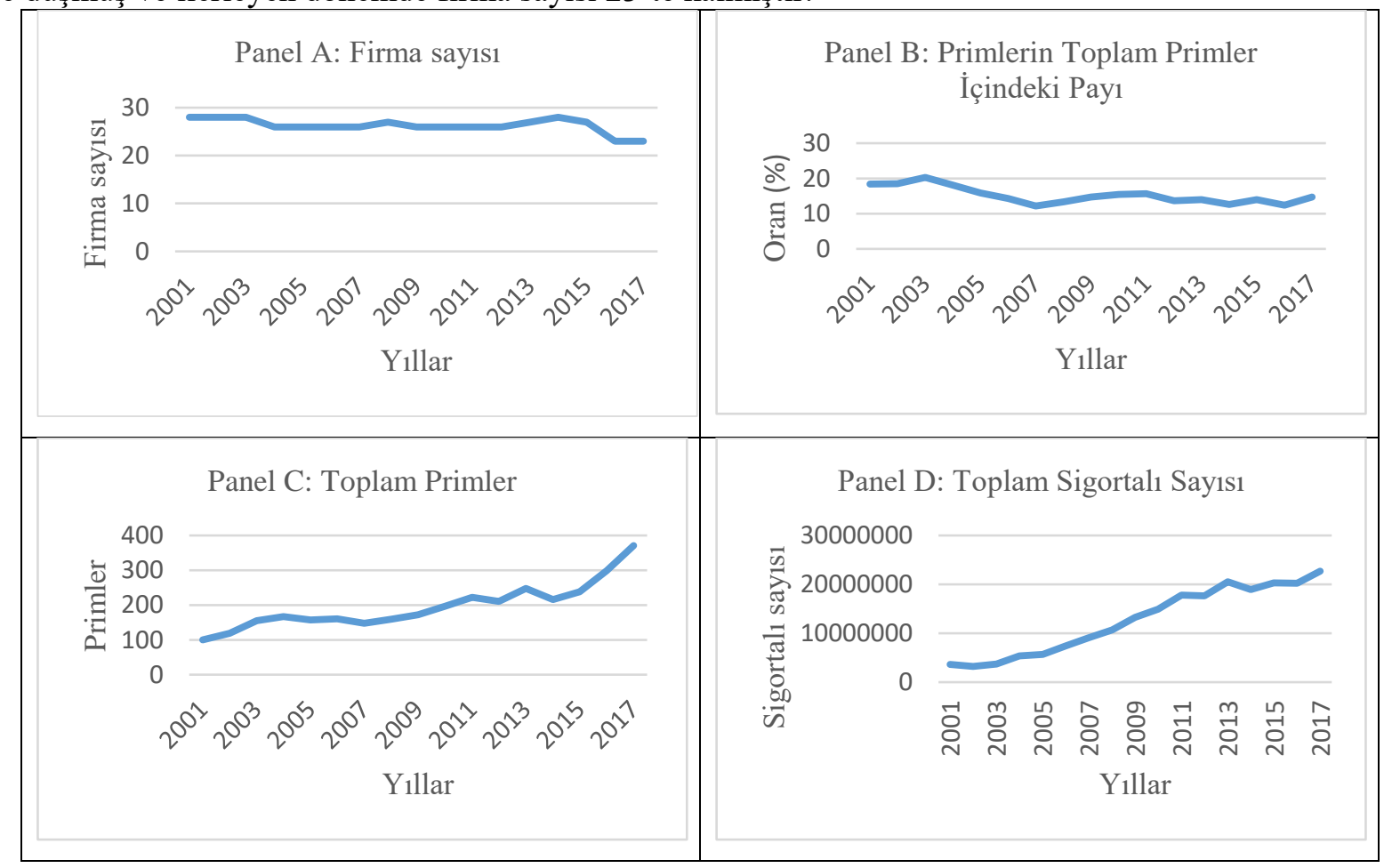

Şekil 1: 2000’den sonra Türkiye'de hayat sigortası piyasasının temel göstergeleri

Panel B'de resmedilen hayat sigortası primlerinin toplam sigorta primleri içindeki payı da panel A'daki gibi bir seyir izlemektedir. İster istemez bu iki panel yukarıda ifade edilenlerle zıtlık gösterse de, panel C ve panel D, bu piyasanın Türkiye için neden yükselen bir alan olduğu hakkında ipuçları verecektir. Hayat sigortası 
piyasasında faaliyet gösteren firmalar için prim toplamları ve sigortalı sayısının trend olarak pozitif ve artan bir ivme kazandığı görülmektedir. Bu beklenti panel A'daki görünümün bir nedeni olabilir. Panel A'daki görünümün bir diğer nedeni de piyasaya giriş engelleri olabilir. Benzer şekilde sigorta piyasasının hızla geliştiği Türkiye'de diğer sigorta piyasalarının daha hızlı gelişmesi bu piyasadaki yoğunluk düzeyinin bir nedeni olarak ileri sürülebilir.

Günümüz sigorta piyasasındaki rekabetin önemli göstergelerinden biri piyasa yoğunlaşmasıdır. Yoğunlaşma, piyasada bulunan ekonomik faaliyetler ve kaynakların çoğunluğunun piyasada yer alan az sayıda iktisadi ajan tarafindan kontrol edilmesi ya da sahiplenilmesi olarak ifade edilmektedir. Piyasanın yoğunlaşmasının ölçümünde kullanılan en eski ve en basit yöntem piyasadaki firma sayısının tespit edilmesidir. Bu yönteme göre piyasadaki firma sayısı arttıkça yoğunlaşma azalmaktadır (Yıldırım,vd., 2016: 37-38). Ancak bu yöntem piyasada faaliyette bulunan firmaların piyasa paylarına dair yeterince bilgi sunmadığından dolayı araştırmacılar tarafından kullanışlı bir yöntem olarak görülmemektedir. Bu yöntem yerine piyasa yoğunlaşması, genellikle pazardaki firmaların bir kısmının veya tamamının piyasa payları üzerinden ölçülmektedir. Endüstrinin piyasa yoğunlaşmasını ölçmede kullanılan en yaygın yöntem, $C R_{n}$, endüstride yer alan en büyük n firmanın piyasa paylarının toplamının hesaplanmasıdır (Carlton ve Perloff, 2000: 247).

$$
C R_{n}=\sum_{t=1}^{n} S_{i}
$$

$\mathrm{Bu}$ yöntemde yoğunlaşma oranı en büyük $\mathrm{n}$ firmanın piyasa paylarının toplamını göstermektedir. Denklemde yer alan $S_{i}$, firmaların piyasa paylarını temsil etmektedir. $C R_{n}$ yönteminde $\mathrm{n}$ değerinin belirlenmesinde karara bağlanmış bir kesinlik ölçütü bulunmamaktadır. Ancak literatürde çoğunlukla $C R_{4}$ ve $C R_{8}$ tercih edilmektedir. Ayrıca bu tercih ölçüm yönteminin en dezavantajlı yönüdür (Kostakoğlu, 2015: 32). $C R_{n}$ yönteminin bir diğer dezavantajı ise endüstrideki tüm firmaları dikkate almaması, sadece en büyük firmaların piyasa paylarını yansıtmasıdır (Yıldırım, vd., 2016: 41). Piyasadaki en büyük 4 firmanın piyasa payının hesaplanmasının ardından piyasa için piyasa yogunlaşma düzeyi, \%30'dan düşük olursa düşük derecede yoğunlaşmadan, $\% 31$ ile $\% 50$ arasında değer alırsa orta derecede yogunlaşmadan, $\% 51$ ile $\% 70$ arasında değer alırsa yüksek derecede yogunlaşmadan ve \%70'ten yüksek olursa çok yüksek derecede yoğunlaşmadan söz edilebilir (TUIK, 2014). Literatürde $C R_{8}$ indeksinin kullanıldığı bazı ampirik araştırmalarda $C R_{4}$ indeksinin yorumlanmasında kullanılan \%50 düzeyinin, $C R_{8}$ indeksinin yorumlanmasında \%70’e karşılık geldiği belirtilmektedir (Yıldırım, vd., 2016: 41).

Endüstri yoğunlaşmasının ölçümünde sıklıkla tercih edilen bir diğer yöntem de Herfindahl- Hirschman indeksidir. Herfindahl- Hirschman indeksi, $C R_{n}$ indeksinin aksine piyasadaki büyük ve küçük tüm firmaları dikkate almaktadır. Yoğunlaşmanın ölçümü piyasada yer alan firmaların piyasa paylarının karelerinin toplamı alınarak hesaplanmaktadır. Piyasadaki firmaların piyasa paylarının karelerinin alınmasından dolayı piyasada faaliyette bulunan büyük firmaların katkısı, küçük firmaların katkısına göre daha fazla olacaktır. Bu yüzden indeks piyasa payı küçük olan firmalara karşı büyük firmalara daha duyarlıdır (Çermikli, 2014: 21).

\section{$H H I=\sum_{t=1}^{n} S_{i}^{2}$}

Birleşik Devletlerde, şirket birleşmelerinin değerlendirilmesinde bu indeksten yararlanılmaktadır. HHI indeksi ile hesaplanan piyasanın yoğunlaşma oranı 1000 'in altında değer alırsa yoğunlaşmamış piyasa, 1000 ile 1800 arasında değer alırsa orta düzeyde yoğunlaşmış piyasa ve 1800 'ün üzerinde değer alırsa yüksek düzeyde yoğunlaşmış piyasa olarak nitelendirilmektedir (Ünsal, 2010: 475). $C R_{n}$ ve HHI kadar yaygın olmasa da endüstri yoğunlaşmasının ölçümünde kullanılan bir diğer indekste Entropi indeksidir. Bu indeks genel olarak piyasadaki firmaların karşı karşıya kaldığı belirsizliğin derecesini ölçmede kullanılır (Parida, vd. , 2016: 124). Entropi indeksi piyasa yoğunlaşmasının ölçümünde ağırlıklı toplam yöntemini esas alır. Ancak bu durumda ağılıklar firmaların pazar paylarıyla ters orantılıdır. Ağırlıklar, firmaların paylarının karşılıklarının doğal logaritmalarıdır (Lipczynski, vd., 2017: 274).

$$
E I=\sum_{t=1}^{n} S_{i} \log _{e}\left(\frac{1}{S_{i}}\right)
$$

HHI'dan farklı olarak Entropi indeksi piyasadaki firmalar arasındaki eşitsizliği de dikkate almaktadır. EI'nin aldığı değer 0 ise piyasada tam yoğunlaşma görülmektedir. Entropi katsayısı 0 'a yaklaştıkça piyasada yoğunlaşma düzeyi artarken, 0 'dan uzaklaştıkça yoğunlaşma düzeyi azalmaktadır. Entropi indeksinin HHI ve $C R_{n}$ indekslerine göre tercih edilme sebebi firma sayısındaki değişmelerin yoğunlaşma üzerindeki etkisini ölçmedeki başarısıdır (Çermikli, 2014: 21). HHI ve $C R_{n}$ indekslerine göre dezavantajlı yönlerinden birisi hesaplanmasının ve yorumlanmasının karmaşık olmasıdır (Dilek, 2017: 58). Diğeri ise Entropi indeksinin maksimum değerinin firma sayısına bağlı olmasından dolayı farklı büyüklüklerdeki sektörler için karşılaştırılmasının zorluğudur. Ancak, maksimum değeri firma sayısına bağlı olmayan standart bir entropi katsayısı tanımlanarak bu zorluk ortadan kaldırılmaktadır. Entropi değerlerinin firma sayısının logaritmasının 
çarpımı ile elde edilen bu katsayı nispi entropi katsayısı (RE) olarak adlandırılmaktadır. RE, 0 ile 1 arasında değer almaktadır. RE değerleri 0'a yaklaştıkça piyasanın yoğunlaşma düzeyi artmakta, RE değerleri 1'e yaklaştıkça piyasanın yoğunlaşma düzeyi azalmaktadır (Lıpczynski vd., 2017 :275).

Türkiye'de hayat sigortası piyasasının yogunlaşmasının ölçümünde $C R_{4}, C R_{8}, \mathrm{HHI}$, Entropi ve Nispi Entropi indekslerinden faydalanılmış ve elde edilen bulgular Tablo 1'de sunulmaktadır.

Tablo 1: Türkiye'de Hayat Sigorta Piyasasının $\mathrm{CR}_{4}, \mathrm{CR}_{8}, \mathrm{HHI}$, Entropi ve Nisbi Entropi İ́ndeksi ile Hesaplanan Yoğunlaşma Oranları

\begin{tabular}{|c|c|c|c|c|c|c|c|c|c|}
\hline Yıllar & Firma & $\begin{array}{c}\boldsymbol{C R}_{\mathbf{4}} \\
\text { Seğerler }\end{array}$ & $\begin{array}{c}\boldsymbol{C R}_{\mathbf{4}} \\
\text { Indeksine } \\
\text { Göre } \\
\text { Piyasanın } \\
\text { Yoğunlaşma } \\
\text { Düzeyi }\end{array}$ & $\begin{array}{c}\boldsymbol{C R}_{\mathbf{8}} \\
\text { Değerler }\end{array}$ & $\begin{array}{c}\boldsymbol{C R}_{\mathbf{8}} \\
\text { Indeksine } \\
\text { Göre } \\
\text { Piyasanın } \\
\text { Yoğunlaşma } \\
\text { Düzeyi }\end{array}$ & $\begin{array}{c}\text { HHI } \\
\text { Değerler }\end{array}$ & $\begin{array}{c}\text { HHI'ya Göre } \\
\text { Piyasanın } \\
\text { Yoğunlaşma } \\
\text { Düzeyi }\end{array}$ & $\begin{array}{c}\text { EI } \\
\text { Değerler }\end{array}$ & Reğerler \\
\hline 2009 & 26 & 62.904 & Yüksek & 80.160 & Yüksek & 1373.392 & Orta & 2.406 & 0.739 \\
\hline 2010 & 26 & 61.181 & Yüksek & 79.226 & Yüksek & 1316.543 & Orta & 2.454 & 0.753 \\
\hline 2011 & 26 & 58.752 & Yüksek & 79.043 & Yüksek & 1347.386 & Orta & 2.455 & 0.754 \\
\hline 2012 & 26 & 52.664 & Yüksek & 77.045 & Yüksek & 1019.049 & Orta & 2.575 & 0.790 \\
\hline 2013 & 27 & 52.078 & Yüksek & 76.857 & Yüksek & 1050.346 & Orta & 2.558 & 0.776 \\
\hline 2014 & 28 & 49.399 & Orta & 74.336 & Yüksek & 903.332 & Düşük & 2.619 & 0.786 \\
\hline 2015 & 27 & 47.390 & Orta & 73.544 & Yüksek & 861.943 & Düşük & 2.642 & 0.802 \\
\hline 2016 & 23 & 48.296 & Orta & 74.708 & Yüksek & 963.217 & Düşük & 2.588 & 0.825 \\
\hline 2017 & 23 & 46.211 & Orta & 73.242 & Yüksek & 918.380 & Düşük & 2.612 & 0.833 \\
\hline 2018 & 23 & 44.320 & Orta & 72.158 & Yüksek & 858.185 & Düşük & 2.646 & 0.844 \\
\hline
\end{tabular}

Tablo 1'deki $C R_{4}$ indeksinin değerlerine göre Türkiye'de hayat sigortası piyasasında 2009-2013 döneminde yüksek düzeyde yoğunlaşma söz konusu iken, 2014-2018 döneminde yoğunlaşma orta düzeye gerilemiştir. Bu yoğunlaşma oranları 2009-2013 döneminde piyasada rekabetin az olduğuna ve piyasanın oligopolistik yap1 özelliği gösterdiğine işaret ederken, 2014-2018 dönemine ait yoğunlaşma oranları piyasadaki rekabetin arttığına ve piyasanın monopolcü rekabet yapısına göre faaliyet gösterdiğine işaret etmektedir. Ayrıca $C R_{4}$ indeks değerleri 2009-2018 döneminde genel bir düşüş eğilimi göstermektedir. 2009 yılında yoğunlaşma oranı \% 62.9 seviyesinde iken bu oran 2018 y1lında \% 44.3'e gerilemiş̦tir. Tablo 1'deki bir diğer yoğunlaşma düzeyi hesaplama yöntemi $C R_{8}$ indeksidir. Hesaplanan $C R_{8}$ değerleri beşinci sütunda gösterilmektedir. $C R_{8}$ indeksinin değerlerine göre ise Türkiye'de hayat sigortası piyasasında 2009-2018 döneminde yüksek düzeyde yoğunlaşma tespit edilmiştir. Bu yoğunlaşma oranlarına göre 2009-2018 döneminde piyasada rekabet düzeyi düşüktür ve piyasa yapısı oligopolistiktir. $C R_{4}$ indeksinin değerleri gibi $C R_{8}$ indeksinin değerlerinde de 20092018 döneminde genel bir düşüş eğilimi gözlenmiştir. Her iki indeks değerinin yıllar itibari ile azalan bir trend izlemesi Türkiye'de hayat sigortası piyasasında her geçen yıl rekabetin arttı̆̆ ş̧eklinde yorumlanabilir.

Tablo 1'de yer alan bir diğer yoğunlaşma hesaplama yöntemi de HHI'dır. HHI indeksi kullanılarak hesaplanan yoğunlaşma oranları yedinci sütunda yer almaktadır. HHI değerlerine göre 2009-2013 döneminde Türkiye'de hayat sigorta piyasasında orta düzey yoğunlaşma söz konusu iken, 2014-2018 döneminde yoğunlaşma düşük düzeye gerilemiştir. 2014-2018 dönemindeki yoğunlaşma düzeyinin, 2009-2013 dönemindeki yoğunlaşma düzeyinden daha düşük olduğu HHI ve $C R_{4}$ indeks bulguları tarafindan desteklenmektedir. $C R_{n}$ indeks bulgularına benzer olarak HHI değerleri de 2009-2018 döneminde genel bir düşüş eğilimindedir. Bu yoğunlaşma oranlarına göre 2009-2018 döneminde hayat sigortası piyasasında rekabet artmaktadır. Entropi indeksi de Tablo 1'de yer alan indekslerden bir diğeridir. Entropi indeksi değerleri dokuzuncu sütunda raporlanmaktadır. Entropi indeks değerleri 2009-2018 döneminde genel bir yükseliş 
eğilimi göstermektedir. $C R_{4}, C R_{8}$ ve HHI değerlerine benzer şekilde Entropi indeksi değerlerine göre de 20092018 döneminde hayat sigortası piyasasında rekabet artmaktadır. Entropi indeksinin hesaplanmasında karşılaşılan zorlukların üstesinden gelmek için geliştirilen Nispi Entropi indeksinin değerleri de onuncu sütunda sunulmaktadır. Bu değerlere göre de 2009-2018 döneminde Türkiye'de hayat sigortası piyasasında yoğunlaşma düzeyi genel olarak azalan bir trend izlemektedir.

\section{LITERATÜR}

İktisat alan yazınında hayat sigortası piyasasında yoğunlaşmayı ölçen çok sayıda araştırma bulunmaktadır. Richards ve Colenutt (1975), Fenn vd. (2008), Alhassan vd. (2015), Parida ve Acharya (2016), Sharku ve Shehu (2016) gibi çok sayıda araştırmacı piyasa yoğunlaşmasının ölçümünde $C R_{n}$ indekslerinden yararlanmaktadırlar. Bikker ve Leuvensteijn (2008), Brokesova vd., (2016), Jaloudi ve Bakir, (2019) gibi araştırmacılar ise piyasa yoğunlaşmasının ölçümünde HHI'yı tercih etmektedirler. Bunların yanında ayrıca, Parida ve Acharya (2016) ve Dimic vd. (2018) gibi araştırmacılar ise hayat sigortası piyasasının yoğunlaşmasının ölçümünde Entropi indeksinden de yararlanmaktadırlar. Bu indekslerin dışında Tablo 2'den de görüleceği üzere literatürde yoğunlaşmanın ölçümünde Horvath, Hall-Tideman, Ginevicius ve GRS, HallTideman, Rosenbluth, Hannah-Kay, Boone göstergesi ve Kapsamlı Yoğunlaşma indeksleri kullanılmaktadır. $\mathrm{Bu}$ indeksler araştırmanın bir parçası olmadığı için tanımlarına ve ölçümlerine yer verilmemiştir. $\mathrm{Bu}$ araştırmanın literatür kısmı iki alt bölümle tasarlanmıştır. İlk bölümde hayat ve hayat dışı sigorta piyasasındaki yoğunlaşmayı hesaplayan araştırmalara yer verilirken, ikinci alt bölümde Türkiye'de çeşitli piyasalarda yoğunlaşmayı inceleyen araştırmalara yer verilmektedir.

Tablo 2: Literatür Taraması

\begin{tabular}{|c|c|c|c|}
\hline Yazar(lar) & $\begin{array}{l}\text { Dönem ve } \\
\text { Örneklem }\end{array}$ & $\begin{array}{c}\text { İncelenen sektör } \\
\text { ve yoğunlaşmanın } \\
\text { ölçüm yöntemi }\end{array}$ & Bulgular \\
\hline $\begin{array}{l}\text { Richards ve } \\
\text { Colenutt } \\
\text { (1975) }\end{array}$ & $\begin{array}{c}\text { 1960, } 1968 \\
\text { ve } 1972 \\
\text { Birleşik } \\
\text { Krallık }\end{array}$ & $\begin{array}{l}\text { Hayat sigortas1 } \\
\text { piyasası } \\
C R_{2}, C R_{4}, C R_{5} \\
C R_{10} \text { ve Herfindahl } \\
\text { Hirschman } \\
\quad \text { indeksleri }\end{array}$ & $\begin{array}{l}\text { Elde edilen bulgulara göre } 1968 \text { yılına ait verilerden } \\
\text { hesaplanan yoğunlaşma oranları } 1960 \text { yılına ait hesaplanan } \\
\text { yoğunlaşma oranlarından daha yüksektir. Ancak } 1972 \\
\text { yılına ait hesaplanan yoğunlaşma oranları ise } 1960 \text { ve } 1968 \\
\text { yıllarına ait hesaplanan yoğunlaşma oranlarından daha } \\
\text { düşüktür. }\end{array}$ \\
\hline Eisen (1991) & $\begin{array}{l}1987 \\
11 \text { Avrupa } \\
\text { Birliği ülkesi }\end{array}$ & $\begin{array}{l}\text { Hayat ve hayat dişı } \\
\text { sigorta piyasası } \\
C R_{5}, M E C R_{2} \text { ve } \\
M E C R_{3} \text { indeksleri }\end{array}$ & $\begin{array}{l}\text { Regresyon analiziyle elde edilen bulgulara göre hayat ve } \\
\text { hayat dışı sigorta piyasasında minimum verimli firma } \\
\text { büyüklüğü }\left(M E C R_{2} \text { ve } M E C R_{3}\right) \text { ile pazar büyüklüğü } \\
\text { arasında pozitif yönlü ilişki bulunmaktadır. Ayrıca analiz } \\
\text { bulgularında yoğunlaşma oranları ile piyasa büyümesi } \\
\text { arasındaki pozitif yönlü ilişkinin hayat sigorta piyasasına } \\
\text { göre hayat dışı sigorta piyasasında daha belirgin olduğu } \\
\text { tespit edilmiştir. }\end{array}$ \\
\hline $\begin{array}{l}\text { Bikker ve } \\
\text { Leuvensteijn } \\
\quad(2008)\end{array}$ & $\begin{array}{c}\text { 1995-2003 } \\
\text { Hollanda }\end{array}$ & $\begin{array}{c}\text { Hayat sigortası } \\
\text { piyasası } \\
\text { Herfindahl- } \\
\text { Hirschman ve } C R_{5} \\
\text { indeksleri } \\
\end{array}$ & $\begin{array}{l}C R_{5} \text { ve Herfindahl- Hirschman indeksleri hesaplamalarına } \\
\text { göre } 1995-2003 \text { döneminde Hollanda hayat sigorta } \\
\text { piyasasında rekabetçi bir yapı gözlenmektedir. }\end{array}$ \\
\hline $\begin{array}{c}\text { Fenn vd. } \\
(2008)\end{array}$ & $\begin{array}{c}\text { 1995-2001 } \\
14 \text { Avrupa } \\
\text { Birliği ülkesi }\end{array}$ & $\begin{array}{l}\text { Hayat, hayat dişı ve } \\
\text { karma sigorta } \\
\text { piyasası } \\
C R_{5}, C R_{10} \text { ve } C R_{15} \\
\text { indeksleri }\end{array}$ & $\begin{array}{l}\text { Panel veri analizi bulguları ölçeğe göre artan getiri } \\
\text { oranlarının Avrupa Birliği sigorta şirketlerinin büyük } \\
\text { çoğunluğu için tipik olduğunu göstermektedir. Ayrıca } \\
\text { analiz bulgularında hayat, hayat dışı ve karma sigorta } \\
\text { piyasalarındaki yoğunlaşmanın artmasından dolayı sigorta } \\
\text { şirketlerinin artan getiri ölçeklerinden faydalanabildikleri } \\
\text { sonucuna ulaşılmıştır. }\end{array}$ \\
\hline
\end{tabular}




\begin{tabular}{|c|c|c|c|}
\hline $\begin{array}{l}\text { Pope ve Ma } \\
\text { (2008) }\end{array}$ & $\begin{array}{l}\text { 1996-2003 } \\
\text { Gelişmiş ve } \\
\text { gelişmekte } \\
\text { olan } 23 \text { ülke }\end{array}$ & $\begin{array}{c}\text { Hayat dışı sigorta } \\
\text { piyasası } \\
C R_{5} \text { indeksi }\end{array}$ & $\begin{array}{l}\text { Panel veri analizi bulgularına göre piyasa yoğunlaşmasının } \\
\text { sigorta piyasasının karlılığı üzerindeki etkisi piyasa } \\
\text { serbestleşmesinin seviyesine bağlı olarak değişmektedir. } \\
\text { Ayrıca analiz bulgularında piyasa serbestleşmesinin tepe } \\
\text { noktasında piyasa yoğunlaşması ve karlılık arasında negatif } \\
\text { yönlü ilişkiye rastlanırken, dip noktasında ise güçlü pozitif } \\
\text { yönlü ilişkiye rastlanmıştır. }\end{array}$ \\
\hline $\begin{array}{l}\text { Kozak } \\
(2011)\end{array}$ & $\begin{array}{c}\text { 2002-2009 } \\
\text { Polonya }\end{array}$ & $\begin{array}{c}\text { Hayat dışı sigorta } \\
\text { piyasası } \\
C R_{3} \text { ve } C R_{5} \\
\text { indeksleri }\end{array}$ & $\begin{array}{l}C R_{3} \text { ve } C R_{5} \text { indeksleri hesaplamalarına göre } 2002-2009 \\
\text { döneminde Polonya'da hayat dışı sigorta piyasasında orta } \\
\text { düzeyde rekabet görülmektedir. Ayrıca panel veri analizi } \\
\text { bulgularında yoğunlaşma düzeyi ile piyasa büyümesi } \\
\text { arasında negatif yönlü ilişki tespit edilmiştir. }\end{array}$ \\
\hline $\begin{array}{l}\text { Njegomir ve } \\
\text { Stojic (2011) }\end{array}$ & $\begin{array}{l}\text { 2004-2008 } \\
\quad 11 \\
\text { Güneydoğu } \\
\text { Avrupa } \\
\text { ülkesi }\end{array}$ & $\begin{array}{c}\text { Hayat dişı sigorta } \\
\text { piyasası } \\
C R_{5} \text { indeksi }\end{array}$ & $\begin{array}{l}C R_{5} \text { indeksi hesaplamalarına göre 2004-2008 döneminde } \\
11 \text { Güneydoğu Avrupa ülkesinde hayat dışı sigorta piyasası } \\
\text { rekabetçi yapıdadır. Ayrıca panel veri analiz bulgularında } \\
\text { düşük seviyede küreselleşme için yoğunlaşmanın karlılık } \\
\text { üzerinde pozitif yönlü etkisine rastlanılırken, yüksek } \\
\text { düzeyde küreselleşme için yoğunlaşmanın karlılık üzerinde } \\
\text { negatif yönlü etkisine rastlanmıştır. }\end{array}$ \\
\hline $\begin{array}{c}\text { Pervan ve } \\
\text { Kramaric } \\
\text { (2012) }\end{array}$ & $\begin{array}{l}\text { 1999-2009 } \\
\text { Hirvatistan }\end{array}$ & $\begin{array}{l}\text { Hayat dış1 sigorta } \\
\text { piyasası } \\
\text { Herfindahl- } \\
\text { Hirschman ve } C R_{4} \\
\quad \text { indeksleri }\end{array}$ & $\begin{array}{l}\text { Herfindahl- Hirschman ve } C R_{4} \text { indeksleri hesaplamalarına } \\
\text { göre } 1999-2009 \text { döneminde Hırvatistan'da hayat dışı } \\
\text { sigorta piyasasında yoğunlaşma düzeyi yüksektir. Ayrıca } \\
\text { GMM analizi bulgularında HHI ile hesaplanan yoğunlaşma } \\
\text { oranları ile karlılık arasında pozitif yönlü ilişki tespit } \\
\text { edilirken, } C R_{4} \text { indeksi ile hesaplanan yoğunlaşma oranları } \\
\text { ile karlılık arasında negatif yönlü ilişki tespit edilmiştir. }\end{array}$ \\
\hline $\begin{array}{l}\text { Alhassan vd. } \\
\text { (2015) }\end{array}$ & $\begin{array}{c}\text { 2007-2011 } \\
\text { Gana }\end{array}$ & $\begin{array}{l}\text { Hayat ve hayat dişı } \\
\text { sigorta piyasası } \\
\text { Herfindahl- } \\
\text { Hirschman ve } C R_{4} \\
\quad \text { indeksleri }\end{array}$ & $\begin{array}{l}\text { Herfindahl- Hirschman ve } \mathrm{CR}_{4} \text { indeksleri hesaplamalarına } \\
\text { göre hayat sigortası piyasasında yoğunlaşma oranları hayat } \\
\text { dışı sigorta piyasasına göre daha yüksektir. Ayrıca panel } \\
\text { veri analizi bulgularında hayat dışı sigorta piyasasında HHI } \\
\text { yoğunlaşma oranları ile piyasa büyümesi arasında negatif } \\
\text { yönlü, } C R_{4} \text { indeksi yoğunlaşma oranları ile piyasa } \\
\text { büyümesi arasında pozitif yönlü ilişki tespit edilmiştir. Öte } \\
\text { yandan hayat sigortası piyasasında HHI ve } C R_{4} \text { indeksi } \\
\text { yoğunlaşma oranları ile piyasa büyümesi arasında pozitif } \\
\text { yönlü ilişkiye rastlanmıştır. }\end{array}$ \\
\hline $\begin{array}{l}\text { Brokesova } \\
\text { vd. (2016) }\end{array}$ & $\begin{array}{c}\text { 1993-2012 } \\
\text { Slovak } \\
\text { Cumhuriyeti }\end{array}$ & $\begin{array}{c}\text { Hayat sigortas1 } \\
\text { piyasası } \\
\text { Herfindahl- } \\
\text { Hirschman indeksi }\end{array}$ & $\begin{array}{l}\text { Herfindahl- Hirschman indeksi hesaplamalarına göre } \\
\text { 1993-2012 döneminde Slovak Cumhuriyetinde hayat } \\
\text { sigorta piyasasında yoğunlaşma yüksek düzeydedir. Ayrıca } \\
\text { OLS analizi bulgularında yoğunlaşma düzeyi ile karlılık } \\
\text { arasında negatif yönlü ilişki tespit edilmiştir. Öte yandan } \\
\text { OLS analizi bulgularında yoğunlaşma düzeyi ile piyasa } \\
\text { büyümesi arasında anlamlı bir ilişkiye rastlanılmamıştır. }\end{array}$ \\
\hline $\begin{array}{c}\text { Parida ve } \\
\text { Acharya } \\
(2016)\end{array}$ & $\begin{array}{c}2000-2015 \\
\text { Hindistan }\end{array}$ & $\begin{array}{l}\text { Hayat sigortas1 } \\
\text { piyasas1 } \\
C R_{3}, C R_{5}, C R_{10} \\
\text { Herfindahl- } \\
\text { Hirschman, Entropi, } \\
\text { Horvath, Hall- } \\
\text { Tideman, }\end{array}$ & $\begin{array}{l}\text { Araştırmada kullanılan indekslerin hesaplamalarına göre } \\
2000-2015 \text { döneminde Hindistan'da hayat sigortası } \\
\text { piyasasında yoğunlaşma oranları düşüktür. Ancak bu } \\
\text { indeksler arasından HHI, HTI ve GIN indeksleri diğer } \\
\text { indekslere göre piyasanın daha düşük düzeyde } \\
\text { yoğunlaştığını göstermektedir. }\end{array}$ \\
\hline
\end{tabular}




\begin{tabular}{|c|c|c|c|}
\hline & & $\begin{array}{c}\text { Ginevicius ve GRS } \\
\text { indeksleri }\end{array}$ & \\
\hline $\begin{array}{c}\text { Sharku ve } \\
\text { Shehu (2016) }\end{array}$ & $\begin{array}{c}\text { 2005-2015 } \\
\text { Arnavut }\end{array}$ & $\begin{array}{l}\text { Hayat ve hayat dişı } \\
\text { sigorta piyasası } \\
\text { Herfindahl- } \\
\text { Hirschman, } C R_{1} \text { ve } \\
C R_{4} \text { indeksleri } \\
\end{array}$ & $\begin{array}{l}C R_{1} \text { indeksi hesaplamalarına göre hayat sigorta piyasası } \\
\text { hayat dışı sigorta piyasasına göre daha yoğunlaşmıştır. } \\
\text { Ayrıca HHI hesaplamalarında hayat sigorta piyasasında } \\
\text { yüksek düzeyde yoğunlaşma, hayat dışı sigorta piyasasında } \\
\text { ise düşük düzeyde yoğunlaşma tespit edilmiştir. }\end{array}$ \\
\hline $\begin{array}{l}\text { Cummins vd. } \\
\text { (2017) }\end{array}$ & $\begin{array}{l}\text { 1999-2011 } \\
10 \text { Avrupa } \\
\text { Birliği ülkesi }\end{array}$ & $\begin{array}{c}\text { Hayat sigorta } \\
\text { piyasası } \\
C R_{5} \text { indeksi ve } \\
\text { Boone göstergesi }\end{array}$ & $\begin{array}{l}\text { Panel veri analizi bulgularına göre } C R_{5} \text { indeksi ve Boone } \\
\text { göstergesi ile hesaplanan yoğunlaşma oranları ile piyasa } \\
\text { büyüklüğü arasında negatif yönlü ilişki bulunmaktadır. }\end{array}$ \\
\hline $\begin{array}{l}\text { Dimic vd. } \\
\text { (2018) }\end{array}$ & $\begin{array}{l}\text { 2007-2012 } \\
\quad 8 \\
\text { Güneydoğu } \\
\text { Avrupa } \\
\text { ülkesi }\end{array}$ & $\begin{array}{l}\text { Hayat ve hayat dişı } \\
\text { sigorta piyasası } \\
C R_{4} \text {, Herfindahl- } \\
\text { Hirschman, Entropi } \\
\text { ve Gini indeksleri }\end{array}$ & $\begin{array}{l}C R_{4} \text { indeksi hesaplamalarına göre Sırbistan ve } \\
\text { Hırvatistan'da hayat sigorta piyasasında yüksek düzeyde } \\
\text { yoğunlaşma görülürken, diğer ülkelerin hayat sigorta } \\
\text { piyasalarında düşük yoğunlaşma görülmektedir. HHI } \\
\text { hesaplamalarında Güneydoğu Avrupa ülkelerinin hayat } \\
\text { sigorta piyasalarının ortalama olarak zayıf düzeyde } \\
\text { yoğunlaştığı tespit edilmiştir. Ayrıca panel veri analizi } \\
\text { bulgularında yoğunlaşma oranları ile piyasa büyümesi } \\
\text { arasında zayıf negatif yönlü ilişkiye rastlanmıştır. }\end{array}$ \\
\hline $\begin{array}{c}\text { Jaloudi ve } \\
\text { Bakir (2019) }\end{array}$ & $\begin{array}{l}\text { 2000-2016 } \\
\text { Ürdün }\end{array}$ & $\begin{array}{l}\text { Hayat ve hayat dişı } \\
\text { sigorta piyasaları } \\
C R_{5} \text { ve Herfindahl- } \\
\text { Hirschman } \\
\text { indeksleri }\end{array}$ & $\begin{array}{l}C R_{5} \text { ve Herfindahl- Hirschman indeksleri hesaplamalarına } \\
\text { göre } 2000-2016 \text { döneminde Ürdün'de hayat ve hayat dış1 } \\
\text { sigorta piyasalarında yoğunlaşma düzeyi yüksektir. Ayrıca } \\
\text { panel veri analizi bulgularında yoğunlaşma düzeyi ile } \\
\text { varlıkların getiri oranları arasında pozitif yönlü ilişki tespit } \\
\text { edilmiştir. }\end{array}$ \\
\hline
\end{tabular}

Tablo 2'de hayat ve hayat dışı sigorta piyasalarında yoğunlaşma düzeyinin karlılık ya da piyasa büyümesi üzerindeki etkisini inceleyen araştırmalar özetlenmektedir. Piyasa yoğunlaşmasının karlılık üzerindeki etkisini inceleyen araştırmalarda; Njegomir ve Stojic (2011), Pervan ve Kramaric (2012), Jaloudi ve Bakir, (2019) gibi araştırmacılar değişkenler arasında pozitif yönlü ilişki tespit ederken, Pope ve Ma (2008), Brokesova vd. (2016) gibi araştırmacılar ise değişkenler arasında negatif yönlü ilişki tespit etmektedirler. Piyasa yoğunlaşmasının piyasa büyümesi üzerindeki etkisini inceleyen araştırmalarda Eisen (1991), Alhassan vd. (2015) gibi araştırmacılar piyasa yoğunlaşmasının piyasa büyümesi üzerindeki pozitif yönlü etkisine, Kozak (2011), Alhassan vd. (2015), Cummins vd. (2017), Dimic vd. (2018) gibi araştırmacılar ise piyasa yoğunlaşmasının piyasa büyümesi üzerindeki negatif yönlü etkisine rastlamaktadırlar. Brokesova vd. (2016)'nun araştırmasında ise piyasa yoğunlaşmasının piyasa büyümesi üzerinde anlamlı bir etkisine rastlanmamaktadır.

Türkiye'de Çelik ve Kaplan (2007) hayat dışı sigorta piyasası, Özcan ve Çiftçi (2015) mevduat bankacılığı piyasası, Akel vd. (2016) hayat dışı sigorta piyasası, Alagöz vd. (2016) bankacılık piyasası gibi farklı hizmet ve sanayi kolları için piyasa yoğunlaşması ve piyasa etkinliği üzerine araştırmalar yapmışlardır. Örneğin Türkiye için piyasa yoğunlaşması üzerinde hayat dışı sigorta piyasasında az sayıda araştırmaya rastlanırken, hayat sigortası piyasasında araştırmaya henüz rastlanılmamıştır. Bu boşluk araştırmanın temel motivasyonunu oluşturmaktadır.

\section{VERİ VE YÖNTEMIN TANIMLANMASI}

İktisadi yazındaki araştırmalarda piyasa yoğunlaşması ile piyasa etkinliği arasındaki ilişkiyi inceleyen çok sayıda araştırmaya rastlanmaktadır. Bu araştırmalarda piyasa etkinliğini yansıtmada yaygın olarak karlılık ve piyasa büyümesi değişkenleri tercih edilmektedir. Bu nedenle 2009-2018 döneminde Türkiye hayat sigortas1 piyasası yoğunlaşması ve piyasa etkinliği arasındaki ilişkiyi incelemede bu değişkenlerden piyasa büyümesi değişkeni kullanılmaktadır. İncelemede kullanılan değişkenlerin tanım ve kaynakları Tablo 3'te gösterilmektedir. 
Tablo 3: Değişkenlerin Tanımları ve Kaynağı

\begin{tabular}{|c|c|c|}
\hline Değişken & Tanım & Kaynak \\
\hline LTP & Türkiye'de hayat sigortası piyasasının toplam prim üretimleri & $\begin{array}{c}\text { Türkiye Sigorta } \\
\text { Birliği }\end{array}$ \\
\hline LCR $_{4}$ & $\begin{array}{c}\text { Türkiye'de hayat sigortası piyasasının } \\
\mathrm{CR}_{4} \text { indeksi yardımıyla hesaplanan yoğunlaşma oranları }\end{array}$ & $\begin{array}{c}\text { Türkiye Sigorta } \\
\text { Birliği }\end{array}$ \\
\hline LHHI & $\begin{array}{r}\text { Türkiye'de hayat sigortası piyasasının Herfindahl- Hirschman } \\
\text { indeksi yardımıyla hesaplanan yoğunlaşma oranları }\end{array}$ & $\begin{array}{c}\text { Türkiye Sigorta } \\
\text { Birliği }\end{array}$ \\
\hline LENT & $\begin{array}{r}\text { Türkiye'de hayat sigortası piyasasının Entropi indeksi yardımıyla } \\
\text { hesaplanan yoğunlaşma oranları }\end{array}$ & $\begin{array}{c}\text { Türkiye Sigorta } \\
\text { Birliği }\end{array}$ \\
\hline
\end{tabular}

2009 yılından önceki dönemde Türkiye'de hayat sigortası piyasasında faaliyet gösteren şirketlerin aylık verilerine erişilememesinden dolayı araştırmanın analizinde başlangıç yılı 2009 olarak belirlenmiştir. Modeldeki değişkenlere ait serilerin logaritması alınarak analize dâhil edilmiştir.

Literatürde yer alan modellerden de faydalanarak piyasa yoğunlaşması ile piyasa büyümesi arasındaki uzun dönemli ilişki Johansen eş bütünleşme yöntemi ile tespit edilmiştir. Seriler arasında tespit edilen uzun dönemli ilişsinin yönü ve gücü ise DOLS, FMOLS ve CCR tahmincileri kullanılarak analiz edilmiştir. Piyasa yoğunlaşması ile piyasa büyümesi arasındaki ilişki üç farklı model kurularak incelenmiştir. Kurulan modellerin hepsinde de bağımlı değişken olarak piyasa büyümesi yer alırken, birinci modelde bağımsız değişken olarak HHI değerleri, ikinci modelde bağımsız değişken olarak $\mathrm{CR}_{4}$ değerleri, üçüncü modelde bağımsız değişken olarak Entropi değerleri yer almaktadır.

Model 1: $L T P_{t}=\beta_{0}+\beta_{1} L H H I_{t}+\varepsilon_{t}$

Model 2: $L T P_{t}=\beta_{0}+\beta_{1} \mathrm{LCR}_{4 t}+\varepsilon_{t}$

Model 3: $L T P_{t}=\beta_{0}+\beta_{1} L E N T_{t}+\varepsilon_{t}$

Piyasa yoğunlaşması ile piyasa büyümesi arasındaki ilişkiyi incelemeye yönelik kurulan Model 1 araştırmanın temel modelini oluştururken, Model 2 ve Model 3 ise Model 1'in tutarlı sonuç verip vermediğini kontrol etmek amacıyla kurulmuştur. Araştırmada kullanılan yöntemler ve araştırmanın analiz süreci aşağıda sunulmaktadir.

Stokastik sürece sahip zaman serilerinde, serinin durağanlık göstermesi analiz için önem arz etmektedir. Çünkü geliştirilen ekonometrik yöntemlerin çoğunluğu sadece durağan düzeydeki zaman serileri için geçerlidir. Stokastik veya tesadüfi bir değişkenin zaman içinde ortalaması, varyansı ve otokovaryansının sabit olması şeklinde ifade edilen durağanlık kavramı, serinin belli bir değer etrafında dalgalanmasıdır. Durağan olmayan serilerin durağanlaştırılması işleminde fark ya da logaritma alma işlemi takip edilir. Fark alma sonrasında durağan hale gelen seriler, I(1) "entegre seriler" şeklinde tanımlanmaktadır (Bozkurt, 2007, s. 2729).

Durağanlık testleri birim kök testleri yardımıyla yapılabilmektedir. Artırılmış Dickey-Fuller, PhillipsPerron, Ng-Perron ve Kwiatkowski-Phillips-Schmidt-Shin'in yöntemleri bunlardan bazılarıdır. Bu araștırmada durağanlık sınaması Artırılmış Dickey-Fuller ve Philips-Perron birim kök testleri ile yapılacaktır. ADF ve PP testine yönelik denklemler aşağıdaki şekilde yazılabilir (Sevüktekin ve Çınar, 2017, s. 336-378)

$$
\begin{aligned}
& \Delta Y_{t}=\alpha Y_{t-1}+\sum_{j=1}^{p} \alpha_{i} \Delta Y_{t-j}+\varepsilon_{t} \\
& \tau-\text { istatistiği (trend ve sabit yok) } \\
& \Delta Y_{t}=\vartheta+\alpha Y_{t-1}+\sum_{j=1}^{p} \alpha_{i} \Delta Y_{t-j}+\varepsilon_{t} \\
& \tau_{\vartheta}-\text { istatistiği (sabitli) } \\
& \Delta Y_{t}=\vartheta+\beta t+\alpha Y_{t-1}+\sum_{j=1}^{p} \alpha_{i} \Delta Y_{t-j}+\varepsilon_{t} \\
& \tau_{t}-\text { istatistiği (sabitli ve trendli) }
\end{aligned}
$$

ADF yaklaşımında birim kök testi uygulanacak bir denklemde gecikme sayısı olarak gösterilen p'nin alacağ 1 değeri belirlemek için genelde Akaike (AIC) ya da Schwarz (SIC) bilgi kriterlerinden faydalanılmaktadır (Sevüktekin ve Çınar, 2017, s. 336). Test aşamaları ADF birim kök testi ile aynı olan PP testi, ADF testinin aksine bozucu terimler arasında zayıf bağımlılığa ve heterojenliğe izin vermektedir (Kutlar, 2017, s. 161-162). Bu sebepten dolayı çalışmamızda ADF birim kök testinin yanında PP birim kök testinin de kullanılmasına karar verilmiştir. 
Birim kök testleri sonucunda durağan olmadığı tespit edilen serilerin durağan olması için fark ya da logaritma alma işlemi gerekmektedir. Seriyi durağanlaştırmak için fark almak bazı durumlarda yeterli olmakla birlikte bu işlem serilerdeki dalgalanmaları da ortadan kaldırması değişkene ilişkin uzun dönem bilgisinin kaybolmasına yol açmaktadır. Bu sebepten dolayı entegre seriler I(1) arasında analizi mümkün kılan eş bütünleşme analizi uzun dönemli çalışmalar için ilgi odağı olmuştur (Bozkurt, 2007, s. 109).

Eş bütünleşme analizi Engle-Granger ya da Johansen eş bütünleşme testleri kullanılarak gerçekleştirilmektedir. Normalleştirme seçimini kendiliğinden ele almasından, eş bütünleşme vektörü üzerine konulan kısıtların sınanmasına olanak sağlamasından ve Engle-Granger testinde rastlanan belirsizliği barındırmamasından dolayı analizlerde Johansen eşbütünleşme testi daha çok benimsenmektedir (Göktaş vd., 2018, s. 47). Yukarıda ifade edilen üstünlüklerinden dolayı araştırmada Engle-Granger testi yerine Johansen eş bütünleşme testinin kullanılmasına karar verilmiştir. Johansen'in yöntemi VAR modelini esas almaktadır. Buna göre VAR modeli şu şekilde yazılabilir (Greene, 2012, s. 965-966):

$y_{t}=A_{1} y_{t-1}+\cdots+A_{p} y_{t-p}+B x_{t}+u_{t}$

Yukarıdaki eşitlik VEC modeli şeklinde ifade edilirse aşağıdaki gibi yazııır.

$\Delta y_{t}=\Pi y_{t-1}+\sum_{i=1}^{p-1} \Omega_{i} \Delta Y_{t-j}+B x_{t}+u_{t}$

$\Pi=\sum_{i=1}^{p} A_{i}-I, \quad \Omega_{i}=-\sum_{j=i+1}^{p} A_{j}$

Yukarıdaki eşitlikte $y_{t}$ vektöründe parametrelerin eş bütünleşme koşullarını sağlamaları için $\operatorname{rank}(\Pi)=\mathrm{r}<\mathrm{k}$ olmak durumundadır. $\mathrm{Bu}$ eşitliğe göre $\Pi=\alpha \times \beta$ eşitliğini gerçekleştiren $\alpha$ ve $\beta$ şeklinde kxr matrisi bulunmaktadır. Bu matrislerden $\alpha$ ayarlama hızı katsayısını, $\beta$ eş bütünleşme vektörünü temsil etmektedir (Johansen, 1991, s. 1552-1553).

Johansen eş bütünleşme testinde değişkenler arasında eş bütünleşik vektör sayıs1, iz (trace) ve maksimum öz değer istatistikleri yardımıyla yapılmaktadır. İz öz değer istatistikinin sıfır hipotezi, farklı eş bütünsel vektörlerin sayısı r'ye eşit ve ondan az olduğu hipotezi şeklindeki alternatif hipotezi test etmektedir. Maksimum öz değer istatistiği ise farklı eş bütünsel vektörlerin sayısı r'ye eşit ve ondan az olduğu hipotezine karş1 r+1 kadar eş bütünleyen vektör olduğu hipotezi test etmektedir (Kutlar, 2009, s. 384-385)

$$
\begin{aligned}
& \left(\lambda_{i z}\right)=-T \sum_{i=r+1}^{p} \ln \left(1-\lambda_{i}\right) \\
& \left(\lambda_{\text {maks }}\right)=-T \ln \left(1-\lambda_{r+1}\right)
\end{aligned}
$$

Yapılan eş bütünleşme testi sonucunda iz ve öz değer istatistiklerinin kritik değerlerden yukarıda olması durumunda sıfir hipotezi reddedilmiş olmaktadır. Elde edilen bu bulgu değişkenlerin eş bütünleşik olduğunu göstermektedir (Sevüktekin ve Çınar, 2017, s. 589).

Johansen eşbütünleşme testi ile seriler arasındaki uzun dönemli ilişkinin tespitinin ardından, bu ilişkinin yönü ve şiddeti, serilerin I(1)'de yani birinci dereceden farkta durağan olma koşuluna dayanan FMOLS, CCR ve DOLS yöntemleri ile tahmin edilmiştir. Uzun dönemli ilişkinin katsayılarının yorumlanmasına olanak sağlaması, küçük örneklemlerde güvenilir sonuçlar göstermesi ve içsellik sorununu ortadan kaldırması gibi avantajlarından dolayı bu yöntemler araştırmacılar tarafından sıklıkla tercih edilmektedir (Erdoğan, vd., 2018:46-47). Yukarıda belirtilen avantajlarından dolayı bu araştırmada da seriler arasında tespit edilen uzun dönemli ilişkinin tahmininde FMOLS, DOLS ve CCR yöntemlerine başvurulmuştur.

\section{TESTLER VE BULGULAR}

Tahmin modellerinin analizinde ilk olarak serilerin durağanlığı sınanmıştır. Durağanlık sınamaları Tablo 4 'te özetlenmektedir. 
Tablo 4: ADF ve PP Birim Kök Test Sonuçları

\begin{tabular}{|c|c|c|c|c|}
\hline \multirow{2}{*}{ Değişkenler } & \multicolumn{2}{|c|}{ ADF } & \multicolumn{2}{c|}{ PP } \\
\cline { 2 - 5 } & Sabit & Sabit ve Trendli & Sabit & Sabit ve Trendli \\
\hline LTP & -1.377 & -2.252 & -1.349 & -2.370 \\
\hline LCR $_{4}$ & -1.472 & -1.442 & -1.209 & -1.658 \\
\hline LHHI & -1.974 & -2.846 & -1.382 & -2.316 \\
\hline LENT & -2.540 & -3.000 & -1.654 & -2.199 \\
\hline$\Delta$ LTP & $-12.404^{* * *}$ & $-12.353^{* * *}$ & $-12.329^{* * *}$ & $-12.282^{* * *}$ \\
\hline$\Delta \mathrm{LCR}_{4}$ & $-3.085^{* *}$ & $-3.261^{*}$ & $-3.256^{* *}$ & $-3.353^{*}$ \\
\hline$\Delta$ LHHI & $-4.485^{* * *}$ & $-4.525^{* * *}$ & $-2.741^{*}$ & $-3,731^{* * *}$ \\
\hline$\Delta$ LENT & $-4,398^{* * *}$ & $-4.526^{* * *}$ & -1.950 & -1.904 \\
\hline Kritik Değerler & & & & -4.037 \\
\hline$\% 1$ & -3.487 & -4.038 & -3.486 & -3.448 \\
\hline$\% 5$ & -2.886 & -3.448 & -2.886 & -3.149 \\
\hline$\% 10$ & -2.580 & -3.149 & -2.580 & \\
\hline
\end{tabular}

Not: *\%10 anlamlılık düzeyini, **\%5 anlamlılık düzeyini ve ***\%1 anlamlılık düzeyini göstermektedir. $\Delta$ birinci dereceden farklı belirtmektedir.

Tablo 4'e göre değişkenler için sıfır hipotezi kabul edilmektedir. I(0) düzeyinde durağan olmadığı anlaşılan bu serilerin farklarının I(1) alınmasının ardından ADF ve PP birim kök testi ile sınanması sonucunda \%5 anlamlılık düzeyinde durağan oldukları görülmektedir. Bu değerler tabloda yer alan değişkenler arasında eş bütünleyen vektörün varlığının araştırılabileceğini ifade etmektedir. Bu araştırmada değiş̧kenler arasında eş bütünleşmenin varlığının tespiti için ise Johansen'in eşbütünleşme testi uygulanmıştır.

$\mathrm{Bu}$ amaçla ilk olarak değişkenler arasındaki ilişkiyi açıklamakta kullanılan modeller için uygun gecikme uzunluğu Akaike ve Schwarz Bilgi Kriterler yardımıyla belirlenmiştir. Bu bilgi kriterlerine göre Model 1, Model 2 ve Model 3 için uygun gecikme uzunluğu beştir. Gecikme uzunluğunun belirlenmesinin ardından Johansen eş bütünleşme testine geçilmiştir. Test bulguları Tablo 5 'te özetlenmektedir.

Tablo 5: Johansen Eş-bütünleşme Testi Bulguları

\begin{tabular}{|c|c|c|c|c|c|c|c|}
\hline \multicolumn{8}{|c|}{ Model 1} \\
\hline \multicolumn{4}{|c|}{ İz Testi } & \multicolumn{4}{|c|}{ Maksimum Öz Değer Testi } \\
\hline$H_{0}$ & $H_{1}$ & Test İstatistiği & Olasılık Değeri & $H_{0}$ & $H_{1}$ & Test İstatistiği & Olasılık Değeri \\
\hline $\mathrm{r}=0$ & $\mathrm{r} \geq 1 *$ & 49.556 & 0.000 & $\mathrm{r}=0$ & $\mathrm{r}=1^{*}$ & 40.396 & 0.001 \\
\hline $\mathrm{r} \leq 1$ & $\mathrm{r}=2^{*}$ & 9.160 & 0.003 & $\mathrm{r} \leq 1$ & $\mathrm{r}=2 *$ & 9.160 & 0.003 \\
\hline \multicolumn{8}{|c|}{ Model 2} \\
\hline \multicolumn{4}{|c|}{ İz Testi } & \multicolumn{4}{|c|}{ Maksimum Öz Değer Testi } \\
\hline $\mathrm{r}=0$ & $\mathrm{r} \geq 1 *$ & 13.209 & 0.035 & $\mathrm{r}=0$ & $\mathrm{r}=$ & 12.170 & 0.034 \\
\hline $\mathrm{r} \leq 1$ & $\mathrm{r}=2$ & 1.039 & 0.358 & $\mathrm{r} \leq 1$ & $\mathrm{r}=$ & 1.039 & 0.358 \\
\hline \multicolumn{8}{|c|}{ Model 3} \\
\hline \multicolumn{4}{|c|}{ Iz Testi } & \multicolumn{4}{|c|}{ Maksimum Öz Değer Testi } \\
\hline $\mathrm{r}=0$ & $\mathrm{r} \geq 1 *$ & 15.340 & 0.015 & $\mathrm{r}=0$ & $\mathrm{r}=$ & \begin{tabular}{l|r}
$*$ & 14.697 \\
\end{tabular} & 0.012 \\
\hline $\mathrm{r} \leq 1$ & $r=2$ & 0.644 & 0.483 & $\mathrm{r} \leq 1$ & $\mathrm{r}=$ & 0.644 & 0.483 \\
\hline
\end{tabular}


Not: Uygun gecikme uzunluğunun seçiminde Akaike Bilgi Kriterleri kullanılmış ve her bir eşbütünleşme modeli için optimum gecikme sayısı maksimum 36 gecikme sayısı üzerinden belirlenmiştir. * seriler arasında eşbütünleşmenin varlığını yansıtmaktadır.

Tablo 5'deki İz ve Maksimum öz değerlerine göre \%5 anlamlılık düzeyinde Model 2 ve Model 3 için bir eş bütünleşme ilişkisi tespit edilirken, Model 1 için iki eşbütünleşme ilişkisi tespit edilmiştir. Modeller için eşbütünleşme ilişkisinin tespit edilmesinin ardından seriler arasındaki ilişki DOLS, FMOLS ve CCR yöntemleri ile tahmin edilmiştir. Modellerin DOLS, FMOLS ve CCR yöntemleri ile tahmin edilmesi sonucu elde edilen bulgular Tablo 6'da özetlenmektedir.

\section{Tablo 6: DOLS, FMOLS ve CCR Tahmin Bulguları}

\begin{tabular}{|c|c|c|c|c|c|c|}
\hline Modeller & \multicolumn{2}{|c|}{ DOLS } & \multicolumn{2}{|c|}{ FMOLS } & \multicolumn{2}{|c|}{ CCR } \\
\hline \multirow[t]{2}{*}{ Model 1} & LHHI & Sabit & LHHI & Sabit & LHHI & Sabit \\
\hline & $\begin{array}{c}-0.737 * * * \\
(-4.479)\end{array}$ & $\begin{array}{c}20.963 * * * \\
(18.348)\end{array}$ & $\begin{array}{c}-0.552 * * * \\
(-3.387)\end{array}$ & $\begin{array}{c}19.756 * * * \\
(17.343)\end{array}$ & $\begin{array}{c}-0.550 * * * \\
(-3.460)\end{array}$ & $\begin{array}{c}19.739 * * * \\
(17.753)\end{array}$ \\
\hline \multirow[t]{2}{*}{ Model 2} & $\mathrm{LCR}_{4}$ & Sabit & $\mathrm{LCR}_{4}$ & Sabit & $\mathrm{LCR}_{4}$ & Sabit \\
\hline & $\begin{array}{c}-1.411 * * * \\
(-5.326)\end{array}$ & $\begin{array}{c}21.430 * * * \\
(20.579)\end{array}$ & $\begin{array}{c}-1.211 * * * \\
(-4.881)\end{array}$ & $\begin{array}{c}20.687 * * * \\
(21.070)\end{array}$ & $\begin{array}{c}-1.207 * * * \\
(-4.979)\end{array}$ & $\begin{array}{c}20.674 * * * \\
(21.505)\end{array}$ \\
\hline \multirow[t]{2}{*}{ Model 3} & LENT & Sabit & LENT & Sabit & LENT & Sabit \\
\hline & $\begin{array}{c}4.421 * * * \\
(4.232)\end{array}$ & $\begin{array}{c}11.696^{* * * *} \\
(11.855)\end{array}$ & $\begin{array}{c}2.985 * * * \\
(3.487)\end{array}$ & $\begin{array}{c}13.116^{* * * *} \\
(16.409)\end{array}$ & $\begin{array}{c}2.968 * * * \\
(3.593)\end{array}$ & $\begin{array}{c}13.133 * * * \\
(17.033)\end{array}$ \\
\hline
\end{tabular}

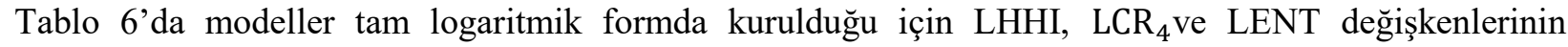
katsayıları, LTP değişkeninin bu değişkenlere olan esnekliğini gösterir. Tablodaki katsayılar incelendiğinde değişkenlerin katsayıları \%1 düzeyinde anlamlılık göstermektedir. Tablo 6'da Model 1 için tahmin edilen DOLS, FMOLS ve CCR değerlerine göre $\mathrm{CR}_{4}$ yoğunlaşma değerleri piyasa büyümesini uzun dönemde negatif yönlü etkilemektedir. Bu etkinin esneklik değeri tahmin yöntemlerine bağlı olarak -0.550 ile -0.737 arasında değişmektedir. Tablo 6' da yer alan Model 2'nin DOLS, FMOLS ve CCR tahmin değerleri HHI yoğunlaşma değerlerinin uzun dönemde piyasa büyümesi üzerindeki negatif yönlü etkisine işaret etmektedir. Bu etkinin esneklik değeri tahmin bulgularına göre -1.207 ile -1.211 arasındadır. Tablo 6'da yer alan Model 3'ün tahminine yönelik DOLS, FMOLS ve CCR değerlerine göre ise Entropi yoğunlaşma değerlerinin piyasa büyümesi üzerindeki uzun dönemde pozitif yönlü etkisi vardır. Bu etkinin esneklik değeri ise 2.985 ile 4.421 arasında değişkenlik göstermektedir. Bu bulgu da Model 1 ve Model 2'nin analiz bulgularını teyit etmektedir. Analiz bulguları hayat sigortasındaki piyasa yoğunlaşması ile piyasa büyümesi arasındaki negatif yönlü ilişkiyi desteklemektedir. Tablo 7'de piyasa yoğunlaşması ve piyasa büyümesi arasındaki ilişkiyi açılamakta kullanılan modellere yönelik olarak kısa dönemde meydana gelen sapmaları uzun dönemde dengeye ulaştıran ayarlama parametre değerleri yer almaktadır.

Tablo 7: Hata Giderme Katsayıları

\begin{tabular}{|c|c|c|c|}
\hline Denge Hatası & Model 1 & Model 2 & Model 3 \\
\hline EC (-1) & -0.050 & -0.061 & -0.051 \\
& $(0.029)$ & $(0.032)$ & $(0.029)$ \\
& {$[-1.734]^{*}$} & {$[-1.913]^{*}$} & {$[-1.743]^{*}$} \\
\hline $\begin{array}{l}\text { Standart hatalar parantez içinde, } \mathrm{t} \text { istatistikleri ise köşeli parantez içinde gösterilmiştir.*\%10 anlamlılık düzeyini, **\%5 } \\
\text { anlamlılık düzeyini,*** \%1 anlamlılık düzeyini belirtmektedir }\end{array}$ \\
\hline
\end{tabular}


Tablo 7'ye göre Model 1 ve Model 3'te meydana gelen bir dengesizliğin \%5'i, Model 2'de meydana gelen bir dengesizliğin \%6'sı birinci ayın sonu itibariyle ortadan kalkmaktadır. Hata düzeltme terimlerinin 0 ile -1 arasında bir değer alması kısa dönemde hata düzelme modelinin doğru işlediğini göstermektedir. Hata düzeltme modelinin doğru işlediğinin belirlenmesinin ardından elde edilen bulguların tutarlılığını kontrol etmek için modellerin değişen varyans ve otokorelasyon içerip içermediği LM ve White testleriyle sınanmıştır. Bulgular Tablo 8'de özetlenmektedir.

Tablo 8: VECM Otokorelasyon ve Değișen Varyans Sınanması Test Bulguları

\begin{tabular}{|c|c|c|c|}
\hline \multicolumn{2}{|c|}{} & Otokorelasyon testi & Değişen Varyans testi \\
\cline { 3 - 4 } \multicolumn{2}{|c|}{} & LM test & White Testi \\
\hline \multirow{2}{*}{$\begin{array}{c}\text { İstatistik } \\
\text { değeri }\end{array}$} & Model 1 & 6.575 & 33.696 \\
\cline { 2 - 4 } & Model 2 & 7.444 & 26.350 \\
\cline { 2 - 4 } & Model 3 & 5.748 & 32.433 \\
\hline \multirow{2}{*}{$\begin{array}{c}\text { Olasılık } \\
\text { değeri }\end{array}$} & Model 1 & 0.160 & 0.579 \\
\cline { 2 - 4 } & Model 2 & 0.114 & 0.336 \\
\cline { 2 - 4 } & Model 3 & 0.219 & 0.639 \\
\hline
\end{tabular}

Tablo 8'de otokorelasyon sınaması için kullanılan LM testi bulgularına göre $\% 5$ anlamlılık düzeyinde Model 1, Model 2 ve Model 3 için belirlenen gecikmelere kadar bir otokorelasyon sorunu tespit edilmemiştir. Ayrıca Tablo 8'de değişen varyanslılık sınaması için kullanılan White testi bulgularına göre $\% 5$ anlamlılık düzeyinde Model 1, Model 2 ve Model 3 için değişen varyansa rastlanılmamıştır.

\section{SONUÇ VE ÖNERILER}

Piyasa yoğunlaşması ile piyasa etkinliği arasındaki ilişki sanayi ekonomisin ele aldığı önemli konulardan biridir. Bu ilişki iktisadi yazında SCP, ES ve RMP hipotezleri çerçevesinde araştırılmaktadır. SCP, ER ve RMP hipotezlerinde piyasa etkinliğini ölçmede karlılık, verimlilik ve piyasa büyümesi faktörleri kullanılmıştır. $\mathrm{Bu}$ hipotezlerden ilki olan SCP hipotezine göre piyasa yoğunlaşmasının piyasa büyümesi üzerinde negatif yönlü etkisi bulunmaktadır. ES hipotezine göre ise piyasa yoğunlaşması ile piyasa büyümesi arasında pozitif yönlü bir ilişki vardır. ES hipotezinin sorgulanmasıyla geliştirilen RMP hipotezine göre ise piyasa yoğunlaşması ile piyasa büyümesi arasındaki ilişkinin yönü piyasadaki lider firmanın piyasa payına bağlıdır.

Bu araştırmada, 2009-2018 döneminde Türkiye hayat sigortası piyasasında piyasa yoğunlaşmasının piyasa büyümesi üzerindeki etkisi mevcut yazında yer alan SCP, ES ve RMP hipotezleri bağlamında incelenmiştir. $\mathrm{Bu}$ araştırma gerçekleştirilirken ilk olarak Türkiye hayat sigortası piyasasının yoğunlaşma düzeyleri $\mathrm{CR}_{4}, \mathrm{CR}_{8}$, HHI, Entropi ve Nispi Entropi indeksleri ile belirlenmiştir. Bu indekslere göre 2009-2018 döneminde Türkiye hayat sigorta piyasasında yoğunlaşma oranları yıllar itibariyle genel olarak azalan bir trend izlemektedir. Piyasa yoğunlaşma düzeylerinin belirlenmesinin ardından piyasa yoğunlaşması ile piyasa büyümesi arasındaki ilişki zaman serisi analiz teknikleri kullanılarak incelenmiştir. Johansen eş bütünleşme testi bulguları piyasanın yoğunlaşma oranlarını yansıtan $\mathrm{CR}_{4}$, $\mathrm{HHI}$ ve Entropi değerleri ile piyasa büyümesi arasında uzun dönemli bir ilişskinin varlığına işaret etmektedir. Bu ilişkinin yönünü belirlemek amacıyla DOLS, FMOLS ve CCR tahmincileri de test edilmiştir. $\mathrm{Bu}$ bağlamda $\mathrm{HHI}$ ve $\mathrm{CR}_{4}$ değerlerinde meydana gelecek olan bir artışın piyasa büyümesi üzerinde bir azalışa neden olacağı tespit edilmiştir. Ayrıca analiz bulgularına göre Entropi değerlerinde meydana gelecek bir artış piyasa büyümesi üzerinde azaltıcı etkiye sahiptir. Bu bulgular SCP hipotezi ile uyumludur. Bu bulgular doğrultusunda piyasanın etkinliğinin artması için politika yapıcılar hayat sigortası piyasasında rekabeti destekleyici politikalar üretmelidir. Ayrıca etkin çalışan bir piyasa sistemi için Rekabet Kurumu gibi rekabeti güçlendiren kurumlar daha aktif hale gelmelidir. Gelecekte bu konuyu incelemeyi düşünen araştırmacılar da hayat sigorta piyasası ile hayat dışı sigorta piyasasını birlikte ele alarak rekabetin hangi piyasada büyüme üzerinde daha etkin olduğunu tespit edebilirler. 


\section{KAYNAKÇA}

Akel, V., Torun, T. ve Aksoy, B. (2016) "Türkiye'de hayat dı̧̧1 sigortacılık sektöründe karlılık, sermaye yapısı ve yoğunlaşma ilişkisine yönelik ampirik bir analiz”, Finans ve Bankacılık Çalışmaları Dergisi, 5(5): 1-15.

Akın, F. ve Nalan, E. (2013) "IMKB'de işlem gören sigorta şirketlerinin 2006-2010 dönemi finansal performanslarının analizi", Muhasebe ve Finansman Dergisi, (57): 89-106.

Alagöz, M., Akalın, U. S. ve Ceylan, O. (2016) "The relationship between concentration and profitably in Turkish banking sector", Journal of Emerging Economies and Policy, 1: 11-18.

Alhassan, A. L., Addisson, G. K. ve Asamoah, M. E. (2015). "Market structure, efficiency and profitably of insurance companies in Ghana", International Journal of Emerging Markets, 10(4): 648-669.

Bikker, J. A. ve Leuvensteijn, M. V. (2008). "Competition and efficiency in the Dutch life insurance industry", Applied Economics, (40): 2063-2084.

Bozkurt, H. (2007). Zaman Serileri Analizi, Ekin Kitabevi, Bursa.

Brokesova, Z., Ondruska, T., Pastorakavo, T. ve Peliova, J. (2016). "Industry concentration and performance: Case of life insurance industry". T. Dudycz, G. Osbert, ve B. B. Bryzcz içinde, In The Essence and Measurement of Organizational Efficiency (s. 29-37), Springer, London.

Carlton, D. W. ve Perloff, J. M. (2000). Modern Industrial Organization, 3. bs., Addison Wesley, NewYork.

Choi, B. P. ve Weiss, M. A. (2005). "An emprical investigation of market structure, efficiency, and performance in proper liability insurance", The Journal of Risk and Insurance, 72(4): 635-673.

Cummins, J. D., Denenberg, H. S. ve Scheel, W. C. (1972). "Concentration in the U.S. life insurance industry", The Journal of Risk and Insurance, 39(2): 177-199.

Cummins, J. D., Rubio-Misas, M. ve Vencappa, D. (2017). "Competition, efficiency and soundness in European life insurance markets", Journal of Financial Stability, (28): 66-78.

Çelik, T. ve Kaplan, M. (2007). "Türk sigortacılık sektöründe karlılık ve yoğunlaşma ilişkisi”, Ankara Üniversitesi SBF Dergisi, 62(4): 70-82.

Çermikli, H. (2014). Endüstriyel İktisat, 2. bs., Gazi Kitapevi, Ankara.

Dilek, S. (2017). Oyun Teorisi Eşliğinde Sanayi Ekonomisi, 2. bs., Seçkin Yayıncılık, Ankara.

Dimic, M., Barjaktarovic, L., Arsenijevic, O., Sprajc, P. ve Zirovnik, J. (2018). "Measuring the concentration of insurance sector: The case of Southeastern European Countries", Organizacija, 51(1): 50-64.

Eisen, R. (1991). "Market size and concentration: Insurance and the European internal market 1992", The Geneva Papers on Risk and Insurance, (16): 263-281.

Erdoğan, L., Tiryaki, A. ve Ceylan, R. (2018). "Türkiye'de uzun dönem ekonomik büyümenin belirleyicilerinin ARDL, FMOLS, DOLS ve CCR yöntemleriyle tahmini”, Hacettepe Üniversitesi İktisadi ve İdari Bilimler Fakültesi Dergisi, 36(4): 39-57.

Fenn, P., Vencappa, D., Diacon, S., Klumpes, P. ve O' Brien, C. (2008). "Market structure and the efficiency of European insurance companies: A stochastic frontier analysis", Journal of Banking \& Finance (32): 86-100.

Greene, W. H. (2012). Econometric Analysis (7. bs.). Pearson Education, Boston.

Göktaş, P., Pekmezci, A. ve Bozkurt, K. (2018). Ekonometrik Serilerde Uzun Dönem Eşbütünleşme ve Kısa Dönem Nedensellik İlişkileri, Gazi Kitapevi, Ankara

Güvel, E. A. ve Güvel, A. Ö. (2012). Sigortacılık, 6. bs., Seçkin Yayıncılık, Ankara.

Jaloudi, M. ve Bakir, A. (2019). "Market structure, efficiency, and performance of Jordan insurance market", International Journal of Business and Economic Research, 8(1): 6-13.

Johansen, S. (1991). "Estimation and hypothesis testing of cointegration vectors in Gaussian vector autoregressive models", Econometrica, 59(6): 1551-1580.

Kozak, S. (2011). "Integration with the European financial system and changes of the non-life insurance sector concentration in Poland", Oeconomia, 10(2): 41-53.

Kutlar, A. (2009). Uygulamalı Ekonometri (3. b.), Nobel Yayın Dağıtım, Ankara

Kutlar, A. (2017). Eviews ile Uygulamalı Zaman Serileri, Umuttepe Yayınları, Kocaeli.

Lipczynski, J., John O.S. ve Wilson, J. G. (2017). Industrial Organization, Competition, Strategy and Policy, 5. bs., Pearson, Harlow.

Njegomir, V. ve Stojic, D. (2011). "Liberalisation and market concentration impact on performance of the non-life insurance", The Geneva Papers on Risk and Insurance, 36(1): 94-106.

Özcan, A. ve Çiftçi, C. (2015). "Türkiye'de mevduat bankacılığında yoğunlaşma ve karlılık ilişkisi (2006-2013 dönemi)”, Niğde Üniversitesi İktisadi ve İdari Bilimler Fakültesi Dergisi, 8(3): 1-12.

Parida, T. K. ve Acharya, D. (2016). "Competition in Indian life insurance industry: Post liberalization evidence", International Journal of Business Competition and Growth, 5(1/2/3): 110-136.

Pope, N. ve Ma, Y.-L. (2008). "The market structure- performance relationship in the international insurance sector", The Journal of Risk and Insurance, 75(4): 947-966.

Richards, K. ve Colenutt, D. (1975). "Concentration in the U.K. ordinary life assurance market", The Journal of Industrial Economics, 24(2): 147-159.

Sevüktekin, M. ve Çınar, M. (2017). Ekonometrik Zaman Serileri Analizi Eviews Uygulamalı, 5.bs., Dora Yayınevi, Bursa. 
Sharku, G. ve Shehu, S. (2016). "Concentration of Albanian insurance market”, Ekonomika a Management (3): 1-11. TSB (2019). Türkiye Sigorta Birliği, https://www.tsb.org.tr/resmi-istatistikler.aspx?pageID=909.

TUİK (2014). "Sanayi ve hizmet sektöründe yoğunlaşma", erişim tarihi 18.03.2019, http://www.tuik.gov.tr/PreHaberBultenleri.do?id=16195.

Ünsal, E. M. (2010). Mikro İktisat, 8. bs., İmaj Yayınevi, Ankara.

Yıldırım, K., Eşkinat, R., Kabasakal, A., Erdoğan, M. ve Kostakoğlu, F. (2016). Endüstriyel Ekonomi, 6.bs., Nisan Kitapevi, Ankara. 